\title{
Model Keterkaitan Inovasi Produk, Citra Merek, Persepsi Nilai dan Intensi Pembelian Produk Kerajinan Tenun Kubang di Sumatera Barat
}

\author{
Ratni Prima Lita, Ranny Fitriana Faisal, Mulia Gusmai, \\ Devi Yulia Rahmi, Meuthia* \\ Fakultas Ekonomi, Universitas Andalas, Indonesia \\ *meuthia@eb.unand.ac.id
}

\begin{abstract}
The aims of this study are to determine and analyze the relationship product innovation, brand image, perceived value and purchase intention in the craft of weaving in the district of Kubang. This study uses a purposive sampling technique with 145 respondents of weaving crafts. The criteria of the sample are consumers (individuals) who know the products weaving. The data analysis uses Partial Least Square-SEM with software Smart PLS. The result of this study shows that : 1) brand image has a significant effect on the perceived value, 2) product innovation has a significant effect on the brand image, 3) perceived value has a significant effect on the purchase intention, and 4) brand image and product innovation are not able to provide a significant effect on purchase intention.
\end{abstract}

Keywords: Brand Image, Product Innovation, Purchase Intention, Perceived Value

\section{PENDAHULUAN}

Usaha Kecil Menengah (UKM) terus dorong untuk berkembang di Indonesia merupakan salah satu negara berkembang. Pertumbuhan UKM diharapkan mendorong pertumbuhan perekonomian Indonesia, membuka lapangan pekerjaan dan meningkatkan pendapatan masyarakat.

UKM yang berkembang di Indonesia adalah usaha kreatif. Kegiatan ekonomi yang didasarkan pada kreativitas, bakat, dan keterampilan individu dalam upaya menciptakan produk yang mempunyai nilai dan menguntungkan bagi masyarakat. Usaha kreatif yang banyak membuka lapangan kerja adalah usaha kuliner, fashion dan kerajinan.

Provinsi Sumatera Barat merupakan salah satu destinasi pariwisata sedang giatnya mengembangkan kerajinan tenun yang termasuk salah satu usaha kreatif. Sumatera
Barat memiliki tiga kerajinan tenun yang terkenal, yakni tenun Kubang, tenun Silungkang, dan tenun Pandai Sikek. Masingmasing tenun memiliki ciri khas dan kualitas yang sangat baik. Motif yang tercipta dari masing-masing tenun sangat unik dan menarik sehingga bisa menjadi cideramata yang khas dari Sumatera Barat.

Tenun Kubang dari Kabupaten Limapuluh Kota mengalami perkembangan yang pesat, setelah mengalami mati suri dan bangkit lagi di tahun 2006. Salah satu Usaha Tenun Kubang yang berkembang pesat adalah UKM yang ada di Kubang, di sumatera Barat yaitu perusahanan tenun H.Ridwan By. Persaingan antar UKM di Sumatera Barat yang menghasilkan produk tenun cukup tinggi karena sama-sama mengandalkan motif tradisonal Minangkabau. Hal ini menuntut pengusaha 
Tenun lebih meningkatkan kreativitas dan inovasi produknya, memperbaiki citra merek dan berupaya meningkatkan persepsi nilai oleh konsumen termasuk UKM H. Ridwan By.

Pengembangan inovasi produk, perbaikan citra merek, dan peningkatan persepsi nilai diharapkan memberikan dampak terhadap intensi membeli produk tenun. Pengusaha berupaya melakukan inovasi produk dengan memperbaiki motifmotif produknya. Hal ini diharapkan mampu mendorong intensi atau minat konsumen membeli produk tenun Kubang. Beberapa penelitian memperlihatkan bahwa inovasi produk mampu mendorong intensi atau minat untuk membeli produk (Shiau, 2014; Wu dan Chen, 2014). Lien et al. (2015) menemukan hasil pada penelitiannya bahwa persepsi nilai secara langsung berpengaruh terhadap intensi atau mina membeli produk. Selanjutnya Chen et al. (2017) menemukan bahwa persepsi nilai mendorong intensi atau minat membeli produk.

Temuan lain memperlihatkan bahwa inovasi produk meningkatkan citra merek sebuah produk (Hanaysha dan Hilman, 2015; Hanaysha, 2016; Shiau, 2014). Selanjutnya hasil penelitian lain tentang citra merek yang mampu mendorong persepsi nilai (Kim et al., 2017; Lien et al., 2015; Y. Te Tu et al., 2013; Y.-T. Tu et al., 2012).

Salah satu strategi perusahaan dalam upaya penerapan proses manufaktur yang lebih produktif, memiliki keunggulan di pasar, membangun persepsi reputasi positif untuk menciptakan keunggulan bersaing yang berkelanjutan (Gunday et al., 2011). Lebih lanjut (Hanaysha, 2016) menyatakan inovasi produk adalah kemampuan perusahaan menghasilkan produk baru yang mempunyai nilai tambah atau mampu meningkatkan produk dan menciptakan persepsi yang baik di benak konsumen.Ada 4 dimensi inovasi produk yakni, teknologi, pelayanan, produk dan terobosan pasar (Shiau, 2014).

Inovasi produk akan memiliki efek pada nilai tambah produk, keberlangsungan hidup organisasi, percepatan pertumbuhan organisasi, efisiensi kinerja, dan profitabilitas yang lebih tinggi (Atalay, 2013). Inovasi produk berpengaruh pada citra merek (Hanaysha dan Hilman, 2015; Shiau, 2014; Shiau, 2014; Kingdom et al., 2016). Berdasarkan penelitian terdahulu, dirumuskan hipotesis 1 yakni:

$\mathrm{H}_{1}$ : Inovasi produk secara signifikan berpengaruh terhadap citra merek produk tenun Kubang.

Intensi pembelian merupakan janji yang secara tersirat yang dilakukan oleh pembeli untuk membeli produk yang sama dilain waktu (Tariq et al., 3013). Intensi pembelian sangat penting bagi perusahaan dalam mendorong penjualan dan profit perusahaan.

Penelitian Wu dan Chen (2014) dan Shiau (2014) menemukan hasil penelitian dimana inovasi produk sebagai antiseden dari kepuasan konsumen. Inovasi produk berdampak terhadap intensi atau minat membeli konsumen terhadap produk, yang kemudian sebagai dasar bagi perusahaan untuk memahami konsumen (Kingdom et al., 2016; Wu dan Chen, 2014). Maka, berdasarkan hal di atas dirumuskan hipotesis 2, yakni:

$\mathrm{H}_{2}$ : Inovasi produk secara signifikan berpengaruh terhadap intensi pembelian produk tenun Kubang.

Shiau (2014), menjamin bahwa citra merek akan membuat konsumen menyimpulkan sendiri kualitas dari sebuah produk. Kesimpulan tersebut membuat konsumen untuk memiliki intensi dalam penelitian (Shiau, 2014). Citra merek mempunyai dampak terhadap minat untuk membeli produk (Jalilvand dan Samiei, 2012, Aghekyan et al., 2012, Wu dan Chang, 2016 dan Basrah, 2017.

Berdasarkan penelitian terdahulu, dirumuskan hipotesis 3 yakni:

$\mathrm{H}_{3}$ : Citra merek secara signifikan berpengaruh terhadap intensi pembelian produk tenun Kubang. 
Persepsi nilai dipengaruhi oleh citra merek, hal demikian dapat membangun hubungan jangka Panjang dengan pelanggan dan sebagai keunggulan bersaing bagi perusahaan (Y. Te Tu et al., 2013). Citra yang positif mempengaruhi persepsi nilai oleh konsumen (Y.-T. Tu et al., 2012). Kim et al. (2017) dan Lien et al. (2015) juga menemukan pada penelitiannya, bahwa citra merek berpengaruh signifikan terhadap persepsi nilai konsumen. Maka hipotesis 4 yakni:

$\mathrm{H}_{4}$ : Citra merek berpengaruh signifikan terhadap persepsi nilai produk tenun Kubang.

Persepsi nilai merupakan pendekatan yang bisa dijadikan dasar oleh perusahan untuk melihat faktor yang mendorong pilihan konsumen, kemauan untuk melakukan pembayaran dan intensi pembelian.

Riviere, (2015) menyebutkan bahwa sebelum melakukan pembelian, konsumen akan membentuk opini dan menentukan pilihan produk. Nilai dari suatu produk akan dirasakan oleh konsumen pada dua titik waktu yang berbeda dalam proses pembelian (Amini et al., 2016). C.-J. Chen et al. (2017) menemukan bahwa persepsi nilai mendorong intensi pembelian atas dasar pertimbangan yang telah dilakukan konsumen terhadap nilai atau manfaat dari suatu produk atau layanan yang dirasakan. Persepsi nilai secara langsung akan berpengaruh terhadap intensi pembelian (Y.R.R Chen, 2017; Lien et al., 2015; J.J. Wang et al., 2018). Berdasarkan hal tersebut, dirumuskan hipotesis 5 yakni:

$\mathrm{H}_{5}$ : Persepsi nilai secara signifikan berpengaruh terhadap intensi membeli prouk tenun Kubang.

Dari kerangka konsep maka model yang diusulkan dalam penelitian adalah terdapat pada Gambar 1:

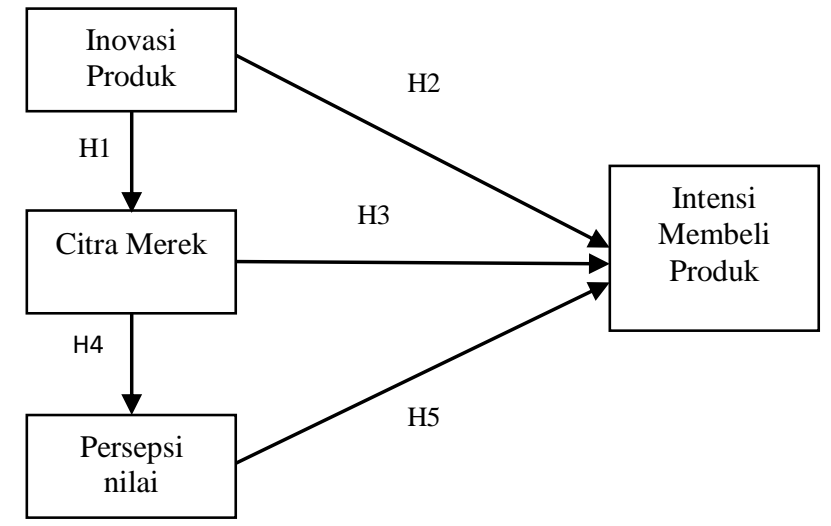

Gambar 1. Model Penelitian

\section{METODE}

Jenis penelitian adalah penelitian eksplanatori (explanatory research). Unit analisis adalah individu yakni konsumen yang mengetahui produk Tenun Kubang yang dihasilkan perusahaan H.Ridwan By di Sumatera Barat. Pengumpulan data dilakukan pada tahun 2018. Data dalam dikumpulkan dengan menggunakan kuesioner. Kuisioner disusun dengan skala Likert 1-5. Variabel diukur menggunakan Skala Likert 1-5 (1=sangat tidak setuju, 5= sangat setuju). Dalam penelitian ini menggunakan purposive sampling. Purposive Sampling merupakan teknik pengambilan sampel dengan menggunakan kriteria tertentu terhadap sampel (Sekaran, 2017). Pada penelitian ini ditentukan kriteria sampel yang diambil adalah konsumen yang mengetahui produk Tenun Kubang yang dihasilkan perusahaan H.Ridwan By dan berumur minimal 17 tahun. Ukuran sampel minimal ditentukan dengan menggunakan cara yaitu jumlah indikator dikalikan lima (Ferdinand 2006). Dalam penelitian ini ada 29 indikator maka ukuran sampel sebesar $29 \times 5$, berarti 145 sampel. Operasionalisasi Variabel seperti Tabel 1:

Tabel 1. Operasionalisasi Variabel

\begin{tabular}{|c|c|c|c|}
\hline Variabel & Dimensi & Indikator & Sumber \\
\hline $\begin{array}{l}\text { Inovasi } \\
\text { produk }\end{array}$ & $\begin{array}{l}\text { Inovasi } \\
\text { Teknologi }\end{array}$ & $\begin{array}{l}\text { 1) Motif produk lebih baik dari } \\
\text { motif produk lain. } \\
\text { 2) Tekstur bahan lebih halus } \\
\text { dari tekstur bahan produk } \\
\text { pesaing. } \\
\text { 3) Kemampuan produsen } \\
\text { dalam pengembangan } \\
\text { produk dibanding pesaing } \\
\text { 4) Tingkat keberhasilan produk } \\
\text { dibandingdari produk lain. } \\
\text { 5) Memperbarui teknologi }\end{array}$ & $\begin{array}{l}\text { Horng- } \\
\text { Cherng } \\
\text { Shiau, } \\
(2014)\end{array}$ \\
\hline
\end{tabular}




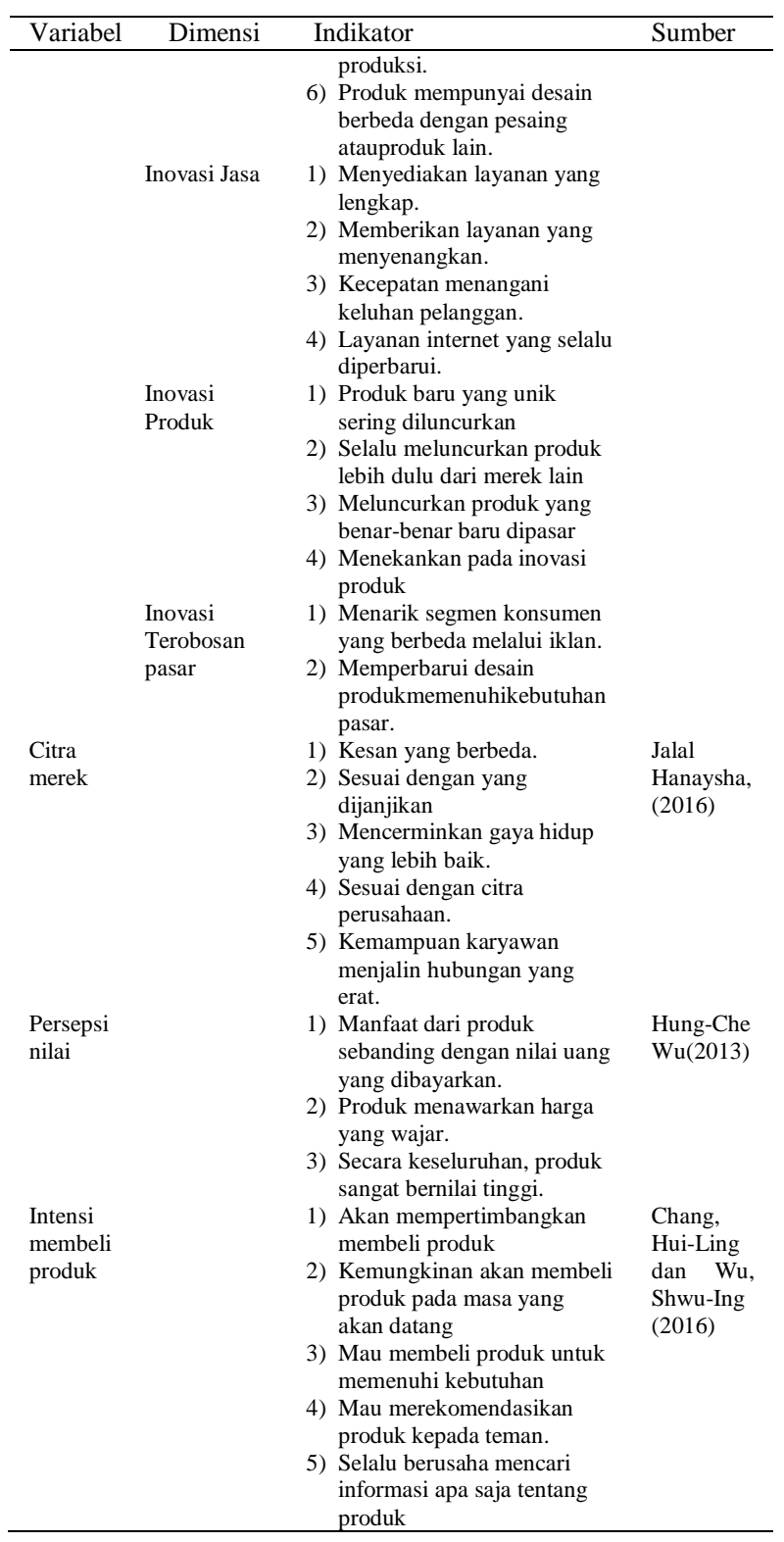

\section{HASIL DAN PEMBAHASAN Profil Responden}

Dari hasil penelitian, ditemukan karakteristik responden seperti Tabel 2:

Tabel 2. Profil Responden

\begin{tabular}{ll}
\hline \multicolumn{1}{c}{ Profil Responden } & \multicolumn{1}{c}{ Hasil } \\
\hline Jenis Kelamin & Laki-laki, 44,8\% \\
Umur & Wanita, 55,6\% \\
& $17-20$ tahun, 2,1\% \\
& $21-20$ tahun, 44,8\% \\
& $31-40$ tahun, 9,0\% \\
& $41-50$ tahun, 21,4\% \\
Pekerjaan & Siswa/mahasiswa, 16,6\% \\
& Karyawan swasta, 18,6\% \\
& Petani/ nelayan, 5,5\% \\
& PNS/TNI/polisi, 20,0\% \\
& Wiraswasta,11,7\% \\
& Lainnya, 27,6\% \\
Pendidikan & SD, 4,8\% \\
Terakhir & SMP, 6,2\% \\
& SMA, 35,9\% \\
& Akademi (D3), 13,1\% \\
\hline
\end{tabular}

\begin{tabular}{ll}
\hline Profil Responden & \multicolumn{1}{c}{ Hasil } \\
\hline & Sarjana (S1), 34,5\% \\
& Pascasarjana, (S2/S3) 5,5\% \\
Pendapatan & Rp2.000.000,00, 36,6\% \\
& Rp2.000.000,00-Rp4.000.000,00, 17,9\% \\
& Rp4.000.000,00-Rp6.000.000,00, 25,5\% \\
& Rp6.000.000-Rp8.000.000,11,0\% \\
& Rp8.000.000,00-Rp10.000.000,00, 3,4\% \\
& $>$ Rp10.000.000,00,5,5\% \\
Pernah atau tidak & Pernah, 67,6\% \\
membeli & Belum pernah, 31,7\% \\
Frekuensi & 1 kali, 37,9\% \\
Pembelian & 2 kali, 30,8\% \\
& 3 kali, 3,8\% \\
& $>3$ kali 11,5\% \\
\hline
\end{tabular}

Sumber: data diolah (2019)

Berdasarkan Tabel 2, dapat diketahui bahwa mayoritas responden yang berminat terhadap tenun Kubang adalah wanita. Hasil ini diperkirakan wanita cenderung lebih menyukai berbelanja dibandingkan kaum pria. Diantara responden penelitian, lebih banyak responden yang berusia 21 tahun keatas karena pada usia ini sangat banyak wanita muda yang berprofesi sebagai model dengan menggunakan kain tradisional termasuk kain tenun Kubang ini. Profesi ini kebanyakan dilakukan oleh wanita dengan latar belakang pendidikan SMA. Mayoritas pendapatan perbulan responden rata rata $\mathrm{Rp}$. 4.000.000 sampai dengan Rp. 6.000.000 dan mayoritas responden pernah melakukan pembelian dengan frekuensi pembelian sebanyak 1 kali.

\section{Pengujian Validitas dan Reliabilitas}

Dalam penelitian ini digunakan konstruk second order formative. Pengujian instrumen second order formative yang terdiri dari pengujian validitas dan realibilitas dilakukan sebelum menganalisis structural equation modeling, untuk mengidentifikasi item yang sesuai untuk dianalisis. Pengujian validitas terlihat dari nilaiconvergent validity dan discriminant validity. Nilai convergent validity menunjukkan apakah indikator tertentu dapat mengukur variabel yang bersangkutan atau tidak, dilihat dari nilai AVE dan nilai outer loadings. Validitas indikator ditentukan dengan nilai AVE $>0,5$ dan dari nilai outer loadings $>0,7$.

Setelah itu diperhatikan nilai cross loadings dan latent variable correlation untuk menentukan discriminant validity. Apabila nilai korelasi skor indikator terhadap 
variabelnya lebih besar daripada skor indikator tersebut ke variabel lainnya, maka nilai tersebut memenuhi. Setelah itu dilakukan uji multikolinearitas untuk melihat apakah jawaban responden berpola atau tidak. Setelah semua item penelitian valid, maka baru bisa dilakukan analisis model struktural dengan menguji $R$-Square dan pengujian hipotesis diperoleh dari path coefficient. Tabel-tabel berikut akan menjelaskan ringkasan pengujian menggunakan bantuan software SmartPLS 2.0 .

Tabel 3. Hasil Pengujian Validitas Konvergen

\begin{tabular}{|c|c|c|c|}
\hline \multirow[t]{2}{*}{$\begin{array}{l}\text { Variabel/ } \\
\text { Dimensi }\end{array}$} & \multirow[t]{2}{*}{ Item } & \multicolumn{2}{|c|}{ Validitas Konvergen } \\
\hline & & Factor Loading & AVE \\
\hline Citra & BI1 & 0,807712 & 0,70852 \\
\hline \multirow{3}{*}{ Merek } & BI2 & 0,856137 & \\
\hline & BI3 & 0,851529 & \\
\hline & BI4 & 0,85067 & \\
\hline Inovasi & PIMB2 & 0,73121 & 0,58767 \\
\hline \multirow[t]{13}{*}{ Produk } & PINP1 & 0,7246 & \\
\hline & PINP2 & 0,73647 & \\
\hline & PINP3 & 0,73239 & \\
\hline & PINP4 & 0,7589 & \\
\hline & PISI1 & 0,81899 & \\
\hline & PISI2 & 0,75322 & \\
\hline & PISI3 & 0,79966 & \\
\hline & PITI1 & 0,75997 & \\
\hline & PITI2 & 0,78546 & \\
\hline & PITI3 & 0,79467 & \\
\hline & PITI4 & 0,80201 & \\
\hline & PITI5 & 0,74298 & \\
\hline & PITI6 & 0,7837 & \\
\hline PIM & PIMB1 & 0,861144 & \\
\hline \multirow[t]{4}{*}{ B } & PIMB2 & 0,906086 & 0,78128 \\
\hline & PINP1 & 0,79108 & \\
\hline & PINP2 & 0,829435 & \\
\hline & PINP3 & 0,824799 & \\
\hline \multirow[t]{4}{*}{ PINP } & PINP4 & 0,844284 & 0,67672 \\
\hline & PISI1 & 0,87973 & \\
\hline & PISI2 & 0,86743 & \\
\hline & PISI3 & 0,87622 & \\
\hline \multirow[t]{6}{*}{ PISI } & PISI4 & 0,70766 & 0,69872 \\
\hline & PITI1 & 0,82269 & \\
\hline & PITI2 & 0,84527 & \\
\hline & PITI3 & 0,87784 & \\
\hline & PITI4 & 0,8619 & \\
\hline & PITI5 & 0,77038 & \\
\hline PITI & PITI6 & 0,77141 & 0,68222 \\
\hline Persepsi & PV1 & 0,861372 & 0,70335 \\
\hline \multirow[t]{2}{*}{ nilai } & PV2 & 0,836042 & \\
\hline & PV3 & 0,818004 & \\
\hline Intensi & PI2 & 0,866934 & 0,70608 \\
\hline \multirow[t]{3}{*}{ Pembelian } & PI3 & 0,817063 & \\
\hline & PI4 & 0,852585 & \\
\hline & PI5 & 0,823576 & \\
\hline
\end{tabular}

Sumber: data diolah (2019)

Tabel 3 memuat nilai outer loadings penelitian, terlihat bahwa indikator setiap variabel telah mempunyai nilai $>0,7$. Berdasarkan Tabel 3 juga dapat dilihat nilai AVE pengujian instrumen penelitian sudah $>0,5$. Setelah itu dapat dilakukan pengujian discriminant validity seperti Tabel 4 .
Tabel 4. Hasil Pengujian Discriminant ValidityCross Loadings

\begin{tabular}{|c|c|c|c|}
\hline & $\begin{array}{c}\text { Citr } \\
\mathrm{a}\end{array}$ & $\begin{array}{l}\text { Ino } \\
\text { vasi }\end{array}$ & \\
\hline & Mer & Pro & PI \\
\hline & ek & duk & MB \\
\hline & 0,8 & 0,6 & 0,4 \\
\hline & 077 & 643 & 841 \\
\hline BI1 & 12 & 39 & 45 \\
\hline & 0,8 & 0,6 & 0,5 \\
\hline & 561 & 410 & 637 \\
\hline BI2 & 37 & 36 & 91 \\
\hline & 0,8 & 0,5 & 0,4 \\
\hline & 515 & 946 & 600 \\
\hline BI3 & 29 & 72 & 27 \\
\hline & 0,8 & 0,6 & 0,5 \\
\hline & 506 & 545 & 033 \\
\hline BI4 & 7 & 35 & 89 \\
\hline & & 0,3 & 0,3 \\
\hline & 0,4 & 887 & 373 \\
\hline PI2 & 819 & 17 & 55 \\
\hline & 0,5 & 0,4 & 0,5 \\
\hline & 428 & 816 & 089 \\
\hline PI3 & 49 & 42 & 26 \\
\hline & 0,4 & 0,4 & 0,4 \\
\hline & 948 & 315 & 058 \\
\hline PI4 & 75 & 07 & 7 \\
\hline & 0,5 & 0,4 & 0,4 \\
\hline & 538 & 960 & 684 \\
\hline PI5 & 42 & 72 & 67 \\
\hline & 0,5 & 0,6 & 0,8 \\
\hline PIM & 224 & 085 & 611 \\
\hline B1 & 46 & 64 & 44 \\
\hline & 0,5 & 0,7 & 0,9 \\
\hline PIM & 365 & 312 & 060 \\
\hline B2 & 04 & 1 & 86 \\
\hline & 0,5 & 0,7 & 0,9 \\
\hline PIM & 365 & 312 & 060 \\
\hline B2 & 04 & 1 & 86 \\
\hline & 0,5 & & 0,5 \\
\hline PIN & 303 & 0,7 & 113 \\
\hline P1 & 59 & 246 & 21 \\
\hline & 0,5 & & 0,5 \\
\hline PIN & 303 & 0,7 & 113 \\
\hline P1 & 59 & 246 & 21 \\
\hline & 0,5 & 0,7 & 0,5 \\
\hline PIN & 753 & 364 & 057 \\
\hline P2 & 3 & 7 & 77 \\
\hline & 0,5 & 0,7 & 0,5 \\
\hline PIN & 753 & 364 & 057 \\
\hline P2 & 3 & 7 & 77 \\
\hline & 0,5 & 0,7 & 0,5 \\
\hline PIN & 829 & 323 & 866 \\
\hline P3 & 9 & 94 & 41 \\
\hline & 0,5 & 0,7 & 0,5 \\
\hline PIN & 829 & 323 & 866 \\
\hline P3 & 9 & 94 & 41 \\
\hline & 0,5 & 0,7 & 0,6 \\
\hline PIN & 532 & 588 & 089 \\
\hline P4 & 78 & 95 & 5 \\
\hline & 0,5 & 0,7 & 0,6 \\
\hline PIN & 532 & 588 & 089 \\
\hline $\mathrm{P} 4$ & 78 & 95 & 5 \\
\hline & 0,5 & 0,8 & 0,6 \\
\hline PISI & 759 & 189 & 320 \\
\hline 1 & 65 & 94 & 21 \\
\hline & 0,5 & 0,8 & 0,6 \\
\hline PISI & 759 & 189 & 320 \\
\hline 1 & 65 & 94 & 21 \\
\hline & 0,6 & 0,7 & 0,6 \\
\hline PISI & 062 & 532 & 841 \\
\hline 2 & 43 & 22 & 44 \\
\hline & 0,6 & 0,7 & 0,6 \\
\hline PISI & 062 & 532 & 841 \\
\hline 2 & 43 & 22 & 44 \\
\hline & 0,5 & 0,7 & 0,6 \\
\hline PISI & 910 & 996 & 391 \\
\hline 3 & 86 & 55 & 87 \\
\hline & 0,5 & 0,7 & 0,6 \\
\hline PISI & 910 & 996 & 391 \\
\hline 3 & 86 & 55 & 87 \\
\hline & 0,5 & 0,5 & 0,4 \\
\hline PISI & 350 & 970 & 982 \\
\hline 4 & 54 & 61 & 87 \\
\hline & 0,6 & 0,7 & 0,4 \\
\hline PITI & 422 & 599 & 829 \\
\hline 1 & 08 & 67 & 34 \\
\hline & 0,6 & 0,7 & 0,4 \\
\hline PITI & 422 & 599 & 829 \\
\hline 1 & 08 & 67 & 34 \\
\hline & 0,6 & 0,7 & 0,4 \\
\hline PITI & 508 & 854 & 738 \\
\hline 2 & 77 & 56 & 16 \\
\hline & 0,6 & 0,7 & 0,4 \\
\hline PITI & 508 & 854 & 738 \\
\hline 2 & 77 & 56 & 16 \\
\hline PITI & 0,5 & 0,7 & 0,5 \\
\hline 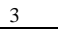 & 970 & 946 & 597 \\
\hline
\end{tabular}




\begin{tabular}{|c|c|c|c|c|c|c|c|c|}
\hline & $\begin{array}{c}\text { Citr } \\
\text { a } \\
\text { Mer } \\
\text { ek }\end{array}$ & $\begin{array}{l}\text { Ino } \\
\text { vasi } \\
\text { Pro } \\
\text { duk }\end{array}$ & $\begin{array}{c}\text { PI } \\
\text { MB }\end{array}$ & $\begin{array}{c}\text { PIN } \\
\text { P }\end{array}$ & $\begin{array}{c}\text { PIS } \\
\text { I }\end{array}$ & $\begin{array}{c}\text { PIT } \\
\text { I }\end{array}$ & $\begin{array}{c}\text { Perc } \\
\text { eive } \\
\mathrm{d} \\
\text { Valu } \\
\mathrm{e}\end{array}$ & $\begin{array}{l}\text { Purch } \\
\text { ase } \\
\text { Intenti } \\
\text { on }\end{array}$ \\
\hline & 37 & 69 & 77 & & 74 & 38 & 3 & \\
\hline & 0,5 & 0,7 & 0,5 & & 0,6 & 0,8 & 0,43 & \\
\hline PITI & 970 & 946 & 597 & 0,59 & 434 & 778 & 293 & 0,422 \\
\hline \multirow[t]{2}{*}{3} & 37 & 69 & 77 & 628 & 74 & 38 & 3 & 026 \\
\hline & 0,6 & 0,8 & 0,5 & 0,68 & 0,5 & 0,8 & 0,43 & \\
\hline PITI & 039 & 020 & 033 & 506 & 884 & 619 & 219 & 0,421 \\
\hline \multirow[t]{2}{*}{4} & 68 & 07 & 38 & 8 & 57 & 04 & 9 & 819 \\
\hline & 0,6 & 0,8 & 0,5 & 0,68 & 0,5 & 0,8 & 0,43 & \\
\hline PITI & 039 & 020 & 033 & 506 & 884 & 619 & 219 & 0,421 \\
\hline \multirow[t]{2}{*}{4} & 68 & 07 & 38 & 8 & 57 & 04 & 9 & 819 \\
\hline & 0,5 & 0,7 & 0,5 & & 0,6 & 0,7 & 0,46 & \\
\hline PITI & 737 & 429 & 491 & 0,64 & 023 & 703 & 458 & 0,400 \\
\hline \multirow[t]{2}{*}{5} & 59 & 83 & 14 & 432 & 21 & 8 & 1 & $\begin{array}{r}960 \\
964\end{array}$ \\
\hline & 0,5 & 0,7 & 0,5 & & 0,6 & 0,7 & 0,46 & \\
\hline PITI & 737 & 429 & 491 & 0,64 & 023 & 703 & 458 & 0,400 \\
\hline \multirow[t]{2}{*}{5} & 59 & 83 & 14 & 432 & 21 & 8 & 1 & 964 \\
\hline & 0,5 & 0,7 & 0,5 & 0,63 & 0,7 & 0,7 & 0,42 & \\
\hline PITI & 242 & 836 & 585 & 726 & 379 & 714 & 434 & 0,407 \\
\hline \multirow[t]{2}{*}{6} & 08 & 97 & 09 & 1 & 96 & 07 & 8 & 856 \\
\hline & 0,5 & 0,7 & 0,5 & 0,63 & 0,7 & 0,7 & 0,42 & \\
\hline PITI & 242 & 836 & 585 & 726 & 379 & 714 & 434 & 0,407 \\
\hline \multirow[t]{3}{*}{6} & 08 & 97 & 09 & 1 & 96 & 07 & 8 & 856 \\
\hline & 0,5 & 0,4 & 0,3 & & 0,4 & 0,4 & 0,86 & \\
\hline & 862 & 724 & 200 & 0,39 & 497 & 570 & 137 & 0,578 \\
\hline \multirow[t]{3}{*}{ PV1 } & 11 & 24 & 19 & 638 & 45 & 25 & 2 & 641 \\
\hline & 0,5 & 0,4 & 0,3 & 0,39 & 0,3 & 0,3 & 0,83 & \\
\hline & 202 & 250 & 640 & 251 & 782 & 839 & 604 & 0,644 \\
\hline \multirow[t]{3}{*}{ PV2 } & 49 & 93 & 17 & 9 & 24 & 4 & 2 & 419 \\
\hline & 0,5 & 0,5 & 0,4 & 0,38 & 0,4 & 0,5 & 0,81 & \\
\hline & 939 & 041 & 150 & 716 & 705 & 015 & 800 & 0,597 \\
\hline PV3 & 62 & 96 & 35 & 1 & 53 & 26 & 4 & 807 \\
\hline
\end{tabular}

Sumber: data diolah (2019)

Apabila nilai loading factor suatu indikator terhadap variabel yang dituju lebih tinggi dibandingkan loading factor terhadap variabel lainnya, maka indikator tersebut dinyatakan valid. Pada Tabel 4 terlihat nilai loading factor indikator terhadap variabelnya lebih besar dibandingkan korelasi indikator tersebut terhadap variabel lain. Discriminat validity terlihat pada nilai latent variabel correlation berikut.

Tabel 5. Hasil Pengujian Discriminant ValidityLatent Variabel Correlation

\begin{tabular}{|c|c|c|c|c|c|c|c|c|}
\hline Variabel & $\begin{array}{l}\text { Citra } \\
\text { Merek }\end{array}$ & $\begin{array}{l}\text { Inovasi } \\
\text { Produk }\end{array}$ & PIMB & PINP & PISI & PIII & $\begin{array}{l}\text { Persepsi } \\
\text { nilai }\end{array}$ & $\begin{array}{l}\text { Intensi } \\
\text { pembelian }\end{array}$ \\
\hline $\begin{array}{l}\begin{array}{l}\text { Citra } \\
\text { merek }\end{array} \\
\text { a }\end{array}$ & $0,84174 *$ & & & & & & & \\
\hline $\begin{array}{l}\text { Inovasi } \\
\text { produk }\end{array}$ & 0,760251 & $\begin{array}{l}\mathbf{0 , 7 6 6 5 9 6} \\
*\end{array}$ & & & & & & \\
\hline PIMB & 0,598549 & 0,7627 & $\begin{array}{l}\mathbf{0 , 8 8 3 9 0 1} \\
*\end{array}$ & & & & & \\
\hline PINP & 0,681333 & 0,89744 & 0,67306 & $\begin{array}{l}\mathbf{0 , 8 2 2 6 6 3} \\
* * 2\end{array}$ & & & & \\
\hline PISI & 0,689002 & 0,89467 & 0,7375 & 0,75387 & $\begin{array}{l}\mathbf{0 , 8 3 5 9 6 8} \\
{ }_{*}\end{array}$ & & & \\
\hline PITI & 0,725112 & 0,94306 & 0,63124 & 0,76439 & 0,76976 & $\begin{array}{l}\mathbf{0 , 8 2 5 9 4 4} \\
*\end{array}$ & & \\
\hline $\begin{array}{l}\text { Persepsi } \\
\text { nilai } \\
\text { Jnten }\end{array}$ & 0,676313 & 0,55764 & 0,43746 & 0,46759 & 0,51659 & 0,53421 & $0,83869 *$ & \\
\hline $\begin{array}{l}\text { Intensi } \\
\text { Membeli } \\
\text { Produk }\end{array}$ & 0,617668 & 0,53571 & 0,51196 & 0,4156 & 0,50318 & 0,52448 & 0,723992 & $0,840289^{*}$ \\
\hline
\end{tabular}

Sumber: data diolah (2019)

Pada Tabel 5 terlihat bahwa korelasi indikator terhadap variabelnya sendiri lebih tinggi dari korelasi variabel tersebut terhadap variabel lainnya. Dengan demikian, konstruk laten memprediksi indikator pada bloknya lebih baik dibandingkan dengan indikator di blok lain. Berdasarkan analisis terhadap output convergent validity dan discriminant validity di atas, dapat disimpulkan bahwa semua indikator pada model reflektif dinyatakan valid. Kemudian dilakukan uji reliabilitas terhadap instrumen reflektif.

Tabel 6. Hasil Pengujian Composite Reliability

\begin{tabular}{cc}
\hline Variabel/ Dimensi & Composite Reliability \\
\hline Citra Merek & 0,9067 \\
Inovasi produk & 0,952206 \\
PIMB & 0,877143 \\
PINP & 0,893259 \\
PISI & 0,902032 \\
PITI & 0,927788 \\
Persepsi nilai & 0,876693 \\
Intensi membeli produk & 0,905694 \\
\hline
\end{tabular}

Sumber: data diolah (2019)

Pada Tabel 6 terlihat variabel mempunyai nilai composite reliability $>0.7$. Oleh karena model yang terbentuk tidak ada permasalahan reliabilitas.

\section{Pengujian Instrumen Second Order Formatif}

Untuk menguji second order formatif digunakan uji multikolinieritas dan uji significance of weight.

\section{Uji Multikolinieritas}

Uji multikolinieritas bertujuan untuk memperlihatkan apakah terdapat jawaban responden yang tidak berpola (gejala multikolinieritas) pada indikator penelitian atau tidak. Ketentuan uji multikolinieritas adalah dilihat dari nilai Variance Inflation Factor (VIF) dan tolerance pada collinearity statistics. Jika nilai $V I F<10$ dan tolerance $>$ 0,1 maka dapat dinyatakan tidak terjadi gejala multikolinieritas. Berikut hasil uji multikolinieritas terlihat pada Tabel 7. 
Tabel 7. Uji Multikolinieritas

\begin{tabular}{|c|c|c|c|c|c|c|c|}
\hline \multirow[t]{2}{*}{ Model } & \multicolumn{2}{|c|}{$\begin{array}{l}\text { Unstandardized } \\
\text { Coefficients }\end{array}$} & \multirow{2}{*}{$\begin{array}{c}\text { Standardized } \\
\text { Coefficients } \\
\text { Beta }\end{array}$} & \multirow[t]{2}{*}{$\mathrm{T}$} & \multirow{2}{*}{ Sig. } & \multirow{2}{*}{$\begin{array}{l}\text { Collinearity } \\
\text { Statistics } \\
\text { Tolerance }\end{array}$} & \multirow[b]{2}{*}{ VIF } \\
\hline & B & Std.Error & & & & & \\
\hline (Constant) & 3,065 & 1,241 & & 2,471 & 0,015 & & \\
\hline PV & 0,826 & 0,13 & 0,488 & 6,358 & 0 & 0,542 & 1,847 \\
\hline BI & 0,173 & 0,112 & 0,166 & 1,547 & 0,124 & 0,276 & 3,629 \\
\hline 1 PITI & 0,119 & 0,085 & 0,148 & 1,396 & 0,165 & 0,282 & 3,546 \\
\hline PISI & 0,082 & 0,134 & 0,066 & 0,614 & 0,54 & 0,276 & 3,619 \\
\hline PINP & $-0,216$ & 0,123 & $-0,177$ & $-1,762$ & 0,08 & 0,317 & 3,159 \\
\hline PIMB & 0,359 & 0,201 & 0,154 & 1,782 & 0,077 & 0,429 & 2,333 \\
\hline
\end{tabular}

Sumber : data diolah (2019)

Dari Tabel 7 terlihat memiliki nilai Variance Inflation Factor (VIF) semua variabel lebih kecil dari 10. Dengan nilai tolerance lebih besar dari 0,1 . Jadi dapat disimpulkan bahwa tidak terjadi gejala multikolinieritas.

\section{Uji Significance of Weights}

Uji significance of weight bertujuan menjelaskan nilai estimasi untuk model pengukuran formatif harus signifikan. Hasil signifikan dilihat dari proses Bootstraping, dengan uji significance of weight diambil dari output outer weights (mean, Std.Dv, Tvalue). Dalam penelitian ini digunakannilai $\mathrm{T}$ tabel sebesar 1,96 (two tailed dengan tingkat kesalahan (Error) adalah 5\%). Jika nilai $\mathrm{T}$ statistik lebih besar dari $\mathrm{T}$ tabel maka indikator dinyatakan valid. Hasil pengujian significance of weights dapat dilihat pada Tabel 8. Indikator yang valid mempunyai tingkat signifikansi yang tinggi, dimana nilai $\mathrm{T}$ statistik besar dari $\mathrm{T}$ tabel. Terlihat bahwa semua indikator mempunyai tingkat signifikansi yang tinggi dengan nilai $T$ statistiknya besar dari $\mathrm{T}$ tabel. Hal ini mengindikasikan bahwa semua indikator memiliki tingkat signifikansi yang kuat terhadap variabelnya.
Tabel 8. Uji Significance of Weights

\begin{tabular}{|c|c|c|c|c|c|}
\hline & $\begin{array}{c}\text { Original } \\
\text { Sample }(O)\end{array}$ & $\begin{array}{c}\text { Sample } \\
\text { Mean }(\mathrm{M})\end{array}$ & $\begin{array}{l}\text { Standard } \\
\text { Deviation } \\
\text { (STDEV) }\end{array}$ & $\begin{array}{l}\text { Standard } \\
\text { Error } \\
\text { (STERR) }\end{array}$ & $\begin{array}{c}\text { T Statistics } \\
(|\mathrm{O} / \mathrm{STERR}|)\end{array}$ \\
\hline $\begin{array}{l}\text { PIMB2 <- } \\
\text { Inovasi } \\
\text { produk }\end{array}$ & 0,089477 & 0,08861 & 0,00549 & 0,00549 & 16,29822 \\
\hline $\begin{array}{l}\text { PINP1 <- } \\
\text { Inovasi } \\
\text { produk }\end{array}$ & 0,085631 & 0,085705 & 0,004113 & 0,004113 & 20,82103 \\
\hline $\begin{array}{l}\text { PINP2 <- } \\
\text { Inovasi } \\
\text { produk }\end{array}$ & 0,085455 & 0,086209 & 0,006404 & 0,006404 & 13,34394 \\
\hline $\begin{array}{l}\text { PINP3 <- } \\
\text { Inovasi } \\
\text { produk }\end{array}$ & 0,090893 & 0,091445 & 0,005076 & 0,005076 & 17,90459 \\
\hline $\begin{array}{l}\text { PINP4 <- } \\
\text { Inovasi } \\
\text { produk }\end{array}$ & 0,090493 & 0,090746 & 0,003817 & 0,003817 & 23,70615 \\
\hline $\begin{array}{l}\text { PISI 1 <- } \\
\text { Inovasi } \\
\text { produk }\end{array}$ & 0,09332 & 0,093925 & 0,005843 & 0,005843 & 15,9712 \\
\hline $\begin{array}{l}\text { PISI2 <- } \\
\text { Inovasi } \\
\text { produk }\end{array}$ & 0,096154 & 0,095913 & 0,004717 & 0,004717 & 20,38264 \\
\hline $\begin{array}{l}\text { PISI3 <- } \\
\text { Inovasi } \\
\text { produk }\end{array}$ & 0,097394 & 0,098065 & 0,005204 & 0,005204 & 18,71497 \\
\hline $\begin{array}{l}\text { PITI1 <- } \\
\text { Inovasi } \\
\text { produk }\end{array}$ & 0,097525 & 0,098181 & 0,005416 & 0,005416 & 18,00646 \\
\hline $\begin{array}{l}\text { PITI2 <- } \\
\text { Inovasi } \\
\text { produk }\end{array}$ & 0,100542 & 0,101083 & 0,006243 & 0,006243 & 16,10358 \\
\hline $\begin{array}{l}\text { PITI3 <- } \\
\text { Inovasi } \\
\text { produk }\end{array}$ & 0,096726 & 0,097515 & 0,005802 & 0,005802 & 16,66985 \\
\hline $\begin{array}{l}\text { PITI4 <- } \\
\text { Inovasi } \\
\text { produk }\end{array}$ & 0,097046 & 0,097829 & 0,005598 & 0,005598 & 17,33514 \\
\hline $\begin{array}{l}\text { PITI5 <- } \\
\text { Inovasi } \\
\text { produk }\end{array}$ & 0,091641 & 0,09273 & 0,006414 & 0,006414 & 14,28746 \\
\hline $\begin{array}{l}\text { PITI6 <- } \\
\text { Inovasi } \\
\text { produk }\end{array}$ & 0,091541 & 0,091956 & 0,004927 & 0,004927 & 18,57809 \\
\hline
\end{tabular}

Sumber: data diolah (2019)

Pengujian Model Struktural dan Hipotesis

Tabel 9 menunjukkan nilai $R$ Square pada variabel yang diamati.

Tabel 9. $R$ Square

\begin{tabular}{cc}
\hline Variabel/ Dimensi & $R$ Square \\
\hline Citra Merek & 0,577982 \\
Inovasi produk & 0,995762 \\
PIMB & \\
PINP & \\
PISI & \\
PITI & \\
Persepsi Nilai & 0,457399 \\
Intensi Membeli Produk & 0,558505 \\
\hline
\end{tabular}

Sumber : data diolah (2019) 
Pada Tabel 9 terlihat nilai $R$ Square inovasi produk sebesar 0,995762. Hal ini memperlihatkan bahwa keempat dimensi inovasi produk (PIMB, PINP, PISI, PITI) mampu menjelaskan variabel inovasi produk sebesar $99 \%$, sedangkan sisa sebesar $1 \%$ dipengaruhi oleh variabel lain yang tidak termasuk dalam penelitian ini. Intensi membeli produk mempunyai nilai $R$ Square $0,558505(55,85 \%)$ artinya intensi membeli produk dipengaruhi oleh citra merek, inovasi produk dan persepsi nilai, sedangkan sisanya sebesar $44,15 \%$ dipengaruhi oleh variabel lain yang tidak diteliti dalam penelitian ini. Semakin tinggi nilai $R$ Square maka semakin besar kemampuan variabel eksogen dapat menjelaskan variabel endogen.

Pengujian hipotesis atau uji signifikansi penelitian dilihat dari nilai $T$-statistics pada Tabel 10. Tingkat signifikansi yang digunakan dalam penelitian ini adalah 0,05 dengan nilai $T$-table yang digunakan adalah 1,96 .

Tabel 10. Path Coefficient

\begin{tabular}{ccc}
\hline & $\begin{array}{c}\text { Original } \\
\text { Sample } \\
\text { Estimate } \\
(\mathrm{O})\end{array}$ & $\begin{array}{c}T \\
\text { Statistics }(\mid \mathrm{O} / \mathrm{ST} \\
\mathrm{ERR} \mid)\end{array}$ \\
\hline $\begin{array}{c}\text { Citra Merek ->Persepsi } \\
\text { nilai }\end{array}$ & 0,676313 & 10,87693 \\
$\begin{array}{c}\text { Citra Merek ->Intensi } \\
\text { membeli produk }\end{array}$ & 0,16577 & 1,632174 \\
$\begin{array}{c}\text { Inovasi Produk -> Citra } \\
\text { Merek }\end{array}$ & 0,760251 & 16,62877 \\
$\begin{array}{c}\text { Inovasi produk ->Intensi } \\
\text { membeli produk }\end{array}$ & 0,099385 & 1,368019 \\
$\begin{array}{c}\text { Persepsi nilai -> Intensi } \\
\text { membeli produk }\end{array}$ & 0,556459 & 7,105102 \\
\hline
\end{tabular}

Sumber: data diolah (2019)

Pada Tabel 10 dapat terlihat bahwa nilai $T$-statistics $>$ T-table pada hipotesis 1 , hipotesis 3 dan hipotesis 5, yang artinya hubungan antara variabel yang diuji adalah signifikan. Namun, hipotesis 2 dan hipotesis 4 diketahui bahwa nilai $T$-statistics $<T$-table berarti hubungan antara variabel yang diuji adalah tidak signifikan. Nilai original sampel estimate yang positif, menunjukkan bahwa arah hubungan antar variabel adalah positif. Sementara, nilai original sampel estimate yang negatif, menunjukkan bahawa arah hubungan antar variabel adalah negatif. Dari hasil penelitian yang tersaji pada Tabel 8 dapat disimpulkan bahwa pengaruh citra merek, inovasi produk, persepsi nilai dan intensi membeli produk adalah positif dan signifikan. Maka dapat disimpulkan Hipotesis 1, Hipotesis 3 dan Hipotesis 5 dapat diterima. Hipotesis 2 dan Hipotesis 4 ditolak dimana citra merek dan inovasi produk tidak berpengaruh secara signifikan terhadap intensi membeli produk tenun Kubang H.Ridwan By.

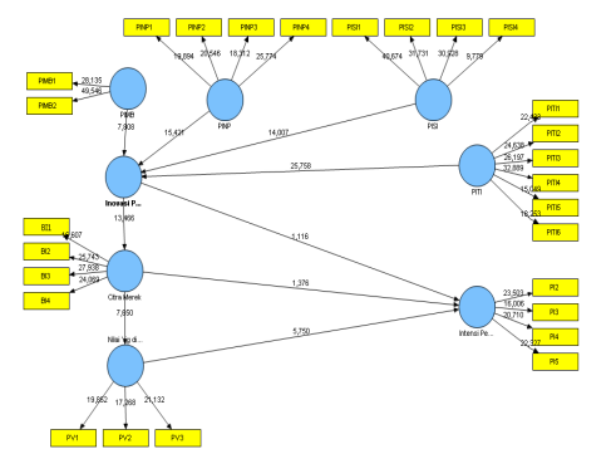

Gambar 2. Full Model yang Ditemukan

\section{Pembahasan}

Penelitian yang telah dilakukan bertujuan untuk mengetahui dan menganalisis keterkaitan inovasi produk, citra merek, persepsi nilai dan intensi membeli produkTenun Kubang H.Ridwan By di Sumatera Barat. Penelitian terdahulu telah membuktikan bahwa citra merek memiliki pengaruh yang signifikan terhadap persepsi nilai (Kim et al., 2017; Lien et al., 2015; Y. Te Tu et al., 2013; Y.T. Tu et al., 2012).

Dalam penelitian ini, secara keseluruhan citra merek berpengaruh signifikan terhadap persepsi nilai. Dari hasil penelitian ditemukan bahwa hipotesis 1 diterima, artinya citra merek berpengaruh terhadap persepsi nilai, dengan nilai $T$ statistics lebih besar daripada T-table $(1,96)$. Hasil penelitian ini mengindikasikan bahwa merek dari tenun Kubang H.Ridwan By telah memberikan kesan yang berbeda kepada konsumen. Kesan yang berbeda yang dirasakan konsumen terhadap produk tenun Kubang akan memberikan kesan yang lebih baik bagi konsumen itu sendiri. Kesan yang baik tersebut dapat muncul dikarenakan kualitas produk, pelayanan yang diberikan 
serta manfaat dari produk. Pemilik usaha tenun Kubang harus mampu menjaga hubungan baik dengan konsumen dengan cara memproduksi produk sesuai dengan permintaan konsumen mulai dari motif, harga, desain, ukuran dan sebagainya, sehingga dengan hubungan tersebut maka konsumen akan memiliki nilai positif dari produk yang dihasilkan perusahaan.

Hasil penelitian ini sejalan dengan penelitian yang dilakukan oleh Jalilvand dan Samiei (2012) bahwa citra merek berpengaruh signifikan terhadap intensi pembelian. Selain itu penelitian ini juga sejalan dengan penelitian terdahulu Aghekyan et al. (2012) ; Wu dan Chang, (2016); Shiau, (2014); Basrah, (2017).

Berdasarkan hasil analisis data dinyatakan hipotesis 2 pengaruh citra merek terhadap intensi pembelian tidak dapat diterima, karena nilai $T$-statistics lebih kecil daripada T-table. Dari 145 responden yang diteliti ditemukan bahwa sebelum melakukan pembelian konsumen tidak memperhatikan citra merek produk yang akan dibelinya. Konsumen lebih memperhatikan kenyamanan dari apa yang dipakainya. Semakin bagus citra merek, tidak akan dapat mempengaruhi minat untuk membeli produk yang ditawarkan. Hal ini dikarenakan bagi sebagian orang citra merek tidaklah penting. Selain itu citra merek tenun produk tenun Kubang H. Ridwan By belum mampu untuk mencerminkan gaya hidup yang lebih baik. Bagi sebagian konsumen produk tersebut tidak mampi memberikan kepercayaan diri kepada konsumen saat menggunakan produk karena desain produk yang terkesan kuno.

Selanjutnya riset terdahulu membuktikan bahwa inovasi produk berpengaruh signifikan dan positif terhadap citra merek (Hanaysha dan Hilman,2015; Hanaysha, 2016;Shiau,2014). Dari hasil penelitian ditemukan bahwa hipotesis 3, dimana inovasi produk berpengaruh terhadap citra merek dapat diterima. Hasil penelitian ini mengindikasikan bahwa secara keseluruhan inovasi produk berpengaruh signifikan terhadap citra merek Tenun Kubang H. Ridwan By. Variabel inovasi produk memiliki 4 dimensi yakni, inovasi teknologi, inovasi jasa, inovasi produk dan inovasi terobosan pasar yang secara bersamasama mampu mempengaruhi citra merek Tenun Kubang H.Ridwan By secara signifikan. Hal ini didorong oleh dengan adanya motif yang bagus yang akan meningkatkan citra perusahaan serta mampu bersaing dengan merek lain, memberikan layanan yang menyenangkan sehingga memperlihatkan bahwa pelayanan yang baik akan mampu meningkatkan citra perusahaan. Selain itu objek juga menekankan pada inovasi produk, hal ini memperlihatkan bahwa semakin meningkatnya inovasi yang dilakukan perusahaan, maka citra perusahaan juga akan semakin meningkat. Memperbarui desain produknya untuk memenuhi kebutuhan pasar, memperlihatkan bahwa desain produk harus diperbarui karena persaingan semakin meningkat, untuk itu inovasi sangat diperlukan. Saat mendesain produk baru perusahaan haruslah melihat kondisi pasar untuk mengetahui apa yang dibutuhkan dipasar saat ini. Sehingga apa yang telah didesain dapat laku dipasar dan mampu memenuhi kebutuhan konsumen.

Selajutnya penelitian Shiau (2014), Kingdom et al., (2016), danWu dan Chen (2014) yang membuktikan bahwa Inovasi produk berpengaruh terhadap intensi pembelian. Namun pada riset ini ditemukan hasil yang berbeda dengan riset sebelumnya. Hal ini mengindikasikan bahwa hipotesis 4 ditolak karena nilai T-statistics lebih kecil daripada T-table. Hasil penelitian ini mengindikasikan bahwa inovasi produk belum mampu mendorong minat konsumen membeli produk tenun Kubang. Hasil penelitian ini berbeda dengan hasil penelitian sebelumnya, dimana inovasi mampu mendorong minat membeli produk. Inovasi produk yang dikembangkan oleh pengusaha Tenun Kubang H.Ridwan By belum mampu menarik minat konsumen di pasar. Hal ini diperkirakan karena tenun Kubang berupaya mempertahankan motif tradisonal Minang, kurang memperbaiki proses produksi dan pembaruan teknik pengerjaanya, sehingga inovasi produk belum optimal. Pengusaha 
bisa melakukan inovasi dari desain yang lebih kekinian sehingga konsumen bisa lebih tertarik membeli produk tenun Kubang tanpa meninggalakn keunikan motif Minangkabau. Teknologi produksi yang digunakan sejak awal berdiri perusahaan hingga saat ini adalah ATBM yang merupakan alat pembuatan tenun tradisional yang mampu menghasilkan produk tenun dengan ciri khas yang unik dan bernilai. Selain itu perusahaan memang tidak menekankan pada inovasi produk, melainkan fokus pada produk yang sudah ada dan produk yang banyak diminati oleh konsumen.

Selanjutnya penelitian Lien et al., (2015) dan Chen et al., (2017) menyatakan bahwa persepsi nilai memiliki pengaruh yang signifikan terhadap intensi pembelian. Hal ini mengindikasikan bahwa hipotesis 5 diterima karena nilai T-statistics lebih besar daripada T-table. Produk yang dihasilkan tenun Kubang H. Ridwan By memberikan manfaat kepada konsumen dimana manfaat tersebut sebanding dengan nilai uang yang telah dibayarkan konsumen atas produk tersebut. Produk yang ditawarkan tenun Kubang $\mathrm{H}$. Ridwan By memiliki harga berkisar Rp300.000 hingga Rp3.500.000. bagi konsumen kelas menengah atas harga ini terbilang wajar mengingat produk tenun merupakan produk tradisional yang berkualitas dan bernilai tinggi. Selain itu, proses pembuatan produk masih menggunakan alat sederhana menggunakan tangan (handmade) sehingga harga produk terbilang mahal jika dibandingkan produk yang diproduksi dengan teknologi canggih seperti penggunaan komputer. Karena pembuatan produk masih menggunakan tangan, maka produk yang dihasilkan memiliki ciri khas tersendiri dan memiliki motif yang berbeda dari pesaing lainnya.

\section{Kesimpulan}

Dari penelitian yang dilakukan dapat disimpulkan bahwa citra merek dan inovasi produk tidak mampu mempengaruhi intensi membeli produk tenun secara signifikan. Hal ini dikarenakan karena banyaknya pesaing saat ini maka konsumen memiliki banyak pilihan merek sebelum melakukan pembelian. Dengan demikian, konsumen tidak lagi memperdulikan merek dari produk melainkan melihat kualitas dan harga yang lebih terjangkau. Hasil penelitian yang dilakukan memperlihatkan inovasi produk yang telah dilakukan pengusaha $\mathrm{H}$. Ridwan By belumlah optimal, hanya beberapa hal saja yang diinovasikan pada usaha ini seperti ukuran kain dan ukuran alat pemintal benang agar lebih efisien. Sedangkan dari segi produk tidak bisa diinovasikan atau dirubah karena kain tenun merupakan produk tradisional yang mana jika dirubah maka akan kehilangan ciri khas dari produk tersebut. Hal inilah yang menyebabkan citra merek dan inovasi produk tidak mampu mempengaruhi intensi pembelian konsumen secara signifikan.

Hasil dari penelitian ini memberikan implikasi terhadap perkembangan ilmu pengetahuan seperti konsep manajemen pemasaran, dimana pengusah bisa memperbaiki strategi pemasarannya terutama inovasi produk, citra merek dan persepsi nilaidimana produk harus memberikan kesan yang berbeda kepada konsumen. Kesan produk yang berbeda dari pesaing lainnya sudah cukup terlihat pada industri tenun Kubang. Hal ini terlihat pada sebagian besar konsumen merasa cukup percaya diri ketika menggunakan produk tenun Kubang H.Ridwan By karena merupakan produk tradisional yang khas dan bernilai tinggi.

Tenun Kubang H.Ridwan By masih belum optimal dalam menghasilkan produk yang unik dan memberikan kesan yang berbeda tersebut kepada konsumen. Hal ini menunjukkan bahwa Tenun Kubang H.Ridwan By harus lebih memperhatikan kesan dari produk agar berbeda dan tidak kalah saing dengan pesaing lainnya. Dengan demikian, perusahaan akan mampu bertahan dalam bidang usaha ini dan memiliki keunggulan dibandingkan pesaing lain serta dapat meningkatkan intensi pembelian produk kerajinan tenun yang akan menghasilkan pendapatan yang nantinya akan mempengaruhi jumlah keuntungan bagi pemilik usaha. 
Beberapa hal yang menjadi batasan dalam penelitian ini dapat dipertimbangkan bagi penelitian selanjutnya, seperti jangkauan penelitian yang terbatas hanya untuk industri kerajinan tenun Kubang H. Ridwan By di di Sumatera Barat. Oleh karena itu, disarankan untuk riset selanjutnya harus menguji variabel-variabel dengan memfokuskan pada daerah lain dan mempertimbangkan jangkauan yang lebih luas.

\section{DAFTAR PUSTAKA}

Ahmad, A., Noor, S. M., Aniza, C., \& Wel, C. (2014). Private Label Merek Produk, 4(2), 101-110.

Alhaddad, A. (2015). Penentu Brand Loyalty, $3,1-8$.

Aghekyan-Simonian, M., Forsythe, S., Suk Kwon, W., \& Chattaraman, V. (2012). The Role of Product Brand Image and Online Store Image on Perceived Risks and Online Purchase Intentions for Apparel. Journal of Retailing and Consumer Services, 19(3), 325-331.

Amini, P., Falk, B., Hoth, N. C., \& Schmitt, R. H. (2016). Statistical Analysis of Consumer Perceived Value Deviation. Procedia CIRP, 51, 1-6.

Atalay, M. (2013). The Relationship between Innovation and Firm Performance : An Empirical Evidence from Turkish Automotive Supplier Industry, 75, 226-235.

August, Ferdinand. 2006. Metode penelitian Manajemen: Pedoman Penelitian untuk skripsi, Tesis dan Disertai Ilmu Manajemen. Semarang: Universitas Diponegoro.

Baskaran, S., Ayob, S. A., Howe, N. C., Mahadi, N., Petra, S. Y., \& E-mail, K. L. (2017). Memahami Pembelian Tujuan dari Ready-to-Eat Food antara urban Malaysia: Sebuah Kerangka Usulan, 7(11), 566-579.

Basrah, S. 2017. (2017). Pengaruh Kualitas Persepsi , Brand Image ,8(1), 1-19.

Bian, X., \& Moutinho, L. (2011). The Role of Brand Image, Product Involvement, and Knowledge in Explaining Consumer Purchase Behaviour of
Counterfeits. European Journal of Marketing, 45(1/2), 191-216.

Chen, Y. R. R. (2017). Perceived Values of Branded Mobile Media, Consumerengagement, BusinessConsumer Relationship Quality and Purchase Intention: A Study of WeChat in China. Public Relations Review, 43(5), 945-954.

Gunday, G., Ulusoy, G., Kilic, K., \& Alpkan, L. (n.d.). Effects of Innovation Types on Firm Performance, (101), 662-676.

Hanaysha, J. (2016). The Importance of Product Innovation in Driving Brand Success: An Empirical Study on Automotive Industry. American Journal of Economics and Business Administration, 8(1), 35-43.

Hanaysha, J., \& Hilman, H. (2015). Management Science Letters, 5, 567576.

Jalilvand, M. R., \& Samiei, N. (2012). The Influence of Electronic Word Mouth on The Brand Image and Purchase Intentions Industry in Iran, 30(4), 460476.

Kim, N., Chun, E., \& Ko, E. (2017). Country of Origin Effects on Brand Image,brand Evaluation, and Purchase Intention. International Marketing Review, 34(2), 254-271.

Kingdom, U., Seng, L. C., \& Ping, N. S. (2016). The Influence Of Product Innovation Toward, Iv(4), 773-782.

Kotler, P., \& Keller, K. L. (2016). Marketing Management. Global Edition (Vol.15E).

Lien, C., Wen, M., Huang, L., \& Wu, K. (2015). Asia Pacific Management Review Online Hotel Booking: The Effects of Brand Image, Price, Trust and Value on Purchase Intentions. Asia Pacific Management Review.

Riviere, A. (2015). Towards a Model of the Perceived Value of Innovation: The Key Role of Perceived Benefits a Head of The Adoption Process. Recherche et Applications En Marketing (English Edition), 30(1), 5-27 
Sekaran, U. (2017). Metode Penelitian untuk Bisnis. (Anita Nur Hanifah, Ed.) (6thed.). Salemba empat.

Shiau, H. (2014). The Impact of Product Innovation on Behavior Intention: The Measurement of the Mediating Effect of the Brand Image of Japanese Anime Dolls, 17(3), 777-788.

Tariq, M. I., Nawaz, M. R., Nawaz, M. M., \& Butt, H. A. (2013). Persepsi pelanggan tentang Branding dan Pembelian Niat: Studi dari FMCG di Pasar Muncul, 3(2), 340-347.

Te Tu, Y., Lien Li, M., \& Chi Chih, H. (2013). An Empirical Study of CorporateBrand Image, Customer Perceived Value and Satisfaction on Loyalty in ShoeIndustry, 3(1), 24-32.
Tu, Y.-T., Wang, C.-M., \& Chang, H.-C. (2012). Corporate Brand Image and Customer Satisfaction on Loyalty: An Empirical Study of Starbucks Coffee in Taiwan. Journal of Social and Development Sciences, 3(1), 24-32.

Wu, S., \& Chang, H. (2016). The Model of Relationship between the Perceived Values and the Purchase Behaviors toward Innovative Products, 7(2), 3145.

Wu, S., \& Chen, Y. (2014). The Impact of Green Marketing and Perceived Innovation on Purchase Intention for Green Products, 6(5), 81-100. 